\title{
USING DATA FROM A REGIONAL INFORMATION FUND OF SOCIAL AND ENVIRONMENTAL HEALTH MONITORING TO ASSESS HUMAN HEALTH RISKS IN LIPETSK ${ }^{1}$
}

\author{
S.I. Savelyev ${ }^{1.3}$, V.A. Bondarev ${ }^{2.3}$, N.V. Nakhichevanskaja ${ }^{2}$, \\ M.F. Polyakova ${ }^{2.3}$, G.A. Yuriev ${ }^{1.3}$, V.M. Saltykov ${ }^{1.3}$, \\ E.A. Golovanova ${ }^{1.3}$
}
${ }^{1}$ Lipetsk Region Department of the Federal Service on Customers Rights Protection and Human Well-Being Surveillance
${ }^{2}$ Federal State Health Care Institution "Hygiene and Epidemiology Center for the Lipetsk Region"
${ }^{3}$ Mechnikov Northwestern State Medical University, St. Petersburg Lipetsk, Russia

\begin{abstract}
In a modern industrial center, where the geographical location of enterprises, landscape features formed in different parts of centers of ecological trouble, there is a problem reasonably choose territory and at-risk populations. The aim of this study was to identify the risk of health problems of the population of Lipetsk under the influence of chemical pollutants in the air and identify priority target programs aimed at reducing anthropogenic pollution of the environment and risk to health of the population. The study was interpolated values of the background concentrations of surveillance to establish the level of risk and confirmed estimates actual levels of morbidity.
\end{abstract}

Keywords: risk assessment, background concentration, regional information collection, environment and health monitoring.

Introduction. Growing air pollution resulting from increased emissions of gases and anthropogenic aerosols is a major environmental risk to health. The implementation of air quality enhancement measures is related to obtaining valid information about the sources and the level of air pollution [1].

The state monitoring system in Lipetsk is based on a network of monitoring stations. Air quality observations are carried out at 8 stations that measure the concentration of 6 to 10 ingredients. Since 2011 continuous monitoring studies have been taking place in the whole of Lipetsk city. Air monitoring in Lipetsk is conducted by the Federal State Budgetary Institution (FSBI) Lipetsk Center for Hydrometeorology and Environmental Monitoring. Field monitoring was performed by a mobile environmental laboratory of Hydraulic Systems Regional Government Agency (RGA) and the laboratory of the FSBI Hygiene and Epidemiology Center for the Lipetsk Region in the residential and industrial areas.

Lipetsk is a contemporary industrial center where the geographical location of the local enterprises, landscape features, and seasonal climatic changes have formed in different parts of the city a few sites of environmental concern; each of the sites has its own set of pollutants. Lipetsk enterprises release 290 thousand tons of pollutants into the atmosphere - $84 \%$ of the total emissions in the region. In 2011, most air pollutants were emitted by NLMK, OJSC - 277.16 thousand tons, Gazpromtransgaz Moscow, LLC branches - 34.3 thousand tons, Lipetskcement, OJSC - 9.6 thousand tons, Quadra - Power Generation Company branch - Eastern Regional Generation - Lipetsk Central Heating and Power Plant-2 - 1.8 thousand tons, LMZ Svobosny Sokol, OJSC - 1.4 thousand tones [4]. In 2011, the amount of cars in Lipetsk increased by 11 thousand units as compared to 2010 and totaled 176.6 thousand units. Respectively, car exhaust emissions (gases) from motor vehicles increased to 60 thousand tons.

\footnotetext{
${ }^{1}$ Translated by Ksenya Zemnlyanova
} 
The purpose of the research is to identify priority health and epidemiological factors that generate negative trends in the state of public health, to adjust targeted programs to protect public health and enhance the environment.

Research methods and data. Atmospheric air was determined to be the environment under analysis; and inhalation was identified as the main way that chemicals entered the human body. Assessment of the influencing concentrations was carried out on the basis of a laboratory environmental monitoring at the monitoring stations

A residential zone scenario selected as reference data focused on chronic (lifelong) exposure that assessed the impact on the residents in a given area regardless their additional exposure to occupational hazards. The description of carcinogenic and non-carcinogenic risks in this paper was generated on the basis of statistically processed annual average concentrations provided by the Lipetsk Center for Hydrometeorology and Environmental Monitoring and Hydraulic Systems company (see Table 1).

Table 1

Average annual concentrations of pollutants based on the data provided by the monitoring stations for 2010-2012

\begin{tabular}{|c|c|c|c|c|}
\hline \multirow{2}{*}{$\begin{array}{c}\text { Monitorin } \\
\text { g station } \\
\text { No. }\end{array}$} & \multirow[t]{2}{*}{ Name of the substance } & \multicolumn{3}{|c|}{$\begin{array}{l}\text { The annual average concentration } \\
(\mathrm{mg} / \mathrm{m} 3)\end{array}$} \\
\hline & & 2010 & 2011 & 2012 \\
\hline 2 & Carbon monoxide & 1 & 1 & 1 \\
\hline 2 & Nitrogen (IY) oxide & 0.01 & 0.01 & 0.01 \\
\hline 2 & Hydrogen sulfide & 0.001 & 0.001 & 0.001 \\
\hline 2 & Phenol & 0.003 & 0.004 & 0.002 \\
\hline 2 & Formaldehyde & 0.008 & 0.005 & 0.007 \\
\hline 3 & Carbon monoxide & 1 & 1 & 1 \\
\hline 3 & Nitrogen (IY) oxide & 0.01 & 0.01 & 0.01 \\
\hline 3 & Nitrogen (II) Oxide & 0.01 & 0.01 & 0.01 \\
\hline 3 & Hydrogen sulfide & 0.002 & 0.002 & 0.002 \\
\hline 3 & Sulfur dioxide & 0.006 & 0.005 & 0.004 \\
\hline 3 & Phenol & 0.003 & 0.004 & 0.002 \\
\hline 3 & Benzo(a)pyrene & 0.000002 & 0.0000016 & $0.0000017^{*}$ \\
\hline 4 & Carbon monoxide & 1 & 1 & 1 \\
\hline 4 & Nitrogen (IY) oxide & 0.01 & 0.01 & 0.01 \\
\hline 4 & Hydrogen sulfide & 0.002 & 0.002 & 0.002 \\
\hline 4 & Phenol & 0.003 & 0.004 & 0.002 \\
\hline 4 & Formaldehyde & 0.007 & 0.005 & 0.006 \\
\hline 5 & Carbon monoxide & 2.15 & 1.09 & 1.02 \\
\hline 5 & Nitrogen (IY) oxide & 0.09 & 0.05 & 0.042 \\
\hline 5 & Formaldehyde & 0.015 & 0.01 & 0.008 \\
\hline 5 & Sulfur dioxide & - & 0.018 & 0.0094 \\
\hline 5 & Benzene & 0.018 & 0.038 & 0.033 \\
\hline 5 & $\begin{array}{l}\text { Xylene (mix of o-, } \mathrm{m}-, \mathrm{p}- \\
\text { isomers ) }\end{array}$ & 0.006 & 0.009 & 0.004 \\
\hline 5 & Toluol & 0.015 & 0.02 & 0.011 \\
\hline 5 & Ethylbenzene & 0.002 & 0.004 & 0.00088 \\
\hline
\end{tabular}




\begin{tabular}{|c|c|c|c|c|}
\hline \multirow{2}{*}{$\begin{array}{c}\text { Monitorin } \\
\text { g station } \\
\text { No. }\end{array}$} & \multirow[t]{2}{*}{ Name of the substance } & \multicolumn{3}{|c|}{$\begin{array}{l}\text { The annual average concentration } \\
(\mathrm{mg} / \mathrm{m} 3)\end{array}$} \\
\hline & & 2010 & 2011 & 2012 \\
\hline 5 & $\begin{array}{l}\text { Lead and its inorganic } \\
\text { compounds (calculated as } \\
\text { lead) }\end{array}$ & 0.00009 & 0.00006 & 0.00015 \\
\hline 6 & Carbon monoxide & 1 & 1 & 1 \\
\hline 6 & Nitrogen (IY) oxide & 0.02 & 0.02 & 0.01 \\
\hline 6 & Hydrogen sulfide & 0.002 & 0.003 & 0.002 \\
\hline 6 & Phenol & 0.002 & 0.004 & 0.002 \\
\hline 6 & Formaldehyde & 0.009 & 0.005 & 0.007 \\
\hline 6 & Benzo(a)pyrene & 0.00000172 & 0.0000015 & $0.0000017^{*}$ \\
\hline 8 & Carbon monoxide & 1 & 1 & 1 \\
\hline 8 & Nitrogen (IY) oxide & 0.01 & 0.02 & 0.01 \\
\hline 8 & Hydrogen sulfide & 0.002 & 0.002 & 0.002 \\
\hline 8 & Phenol & 0.003 & 0.004 & 0.002 \\
\hline 8 & Formaldehyde & 0.007 & 0.004 & 0.006 \\
\hline 8 & Benzo(a)pyrene & 0.00000192 & 0.0000015 & $0.0000017^{*}$ \\
\hline 9 & Carbon monoxide & - & 1.49 & 1.28098 \\
\hline 9 & Nitrogen (IY) oxide & 0.038 & 0.0372 & 0.01909 \\
\hline 9 & Hydrogen sulfide & 0.003 & 0.0031 & 0.002 \\
\hline 9 & Sulfur dioxide & 0.012 & 0.0128 & 0.0055 \\
\hline 9 & Phenol & 0.00299 & 0.0029 & 0.00299 \\
\hline 10 & Carbon monoxide & 0.213 & 1 & 0.9963 \\
\hline 10 & Nitrogen (IY) oxide & 0.02 & 0.01 & 0.0118 \\
\hline 10 & Hydrogen sulfide & 0.003 & 0.003 & 0.0023 \\
\hline 10 & Sulfur dioxide & 0.004 & 0.003 & 0.0034 \\
\hline 10 & Phenol & 0.003 & 0.004 & 0.0022 \\
\hline
\end{tabular}

* - According to preliminary data.

Individual carcinogenic risk (CR) was calculated on the basis of the data on the amount of exposure and carcinogenic potential values (Table 2). Carcinogenic risk was calculated for 5 carcinogens. The range of permissible cancer risks in accordance with the WHO and the EU Commission guidelines was set at 1E-06 [3].

Calculation of non-carcinogenic risk was based on a hazard coefficient (HQ) which is a ratio between the amount of exposure (acceptable daily dose, ADD) and a safe level of exposure (Table 4). Hazard coefficient HQ of less than or equal to 1.0 was taken as acceptable negligible carcinogenic risk of individual chemicals. The value of $\mathrm{HI}=1.0$ [3] was taken as permissible value for the groups of substances that affect the same organs / body systems.

Since this research paper includes a more detailed study of the risks to public health in Lipetsk, the entire residential area was divided into zones based on the service areas of the local clinics (Figure 1). Such division allowed for a more differentiated interpretation of the background concentration values and, as a result, increased health risk assessment accuracy. 


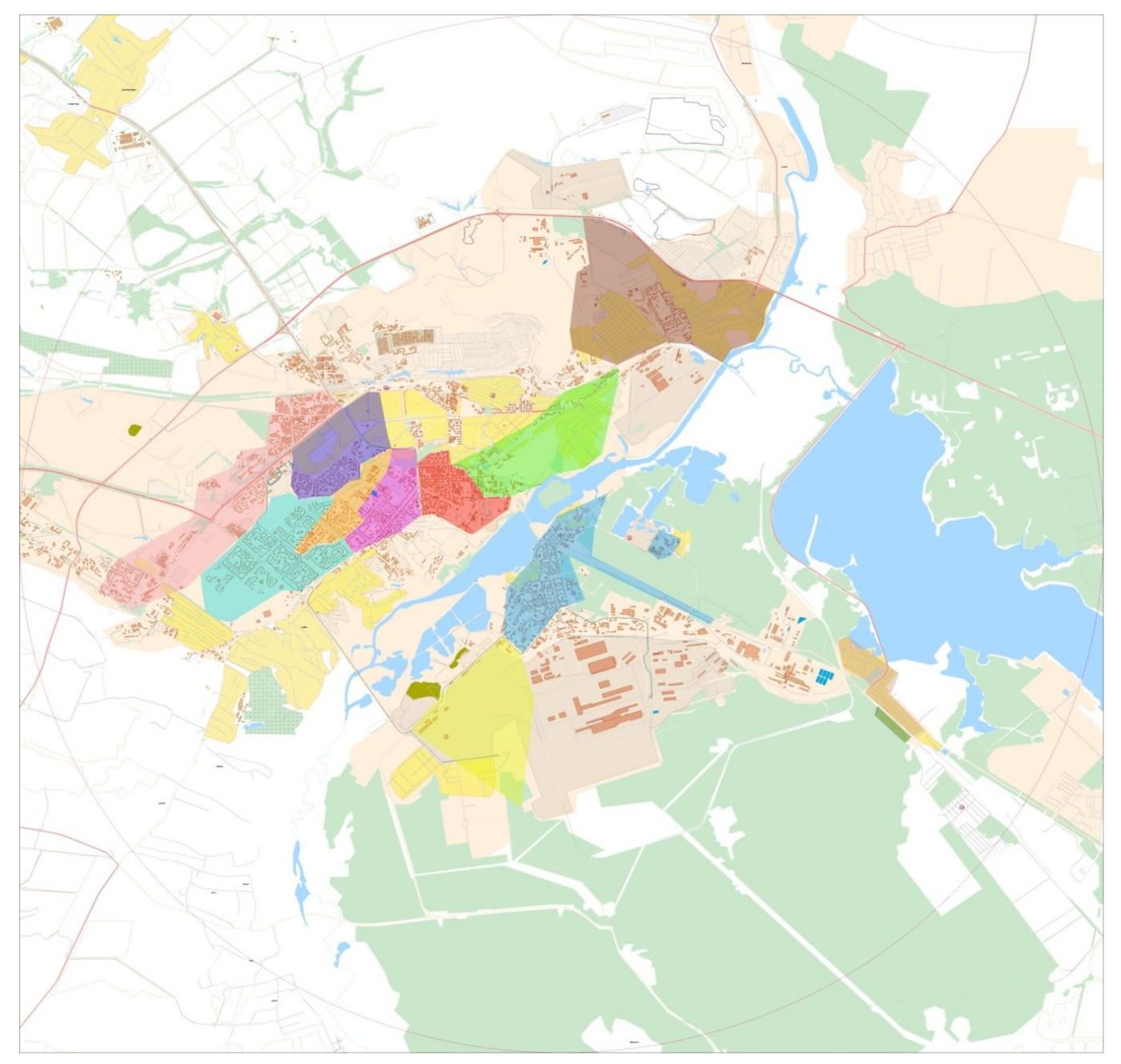

Figure 1: A schematic map of Lipetsk indicating the service areas of local clinics.

The map includes reference points in the most densely populated residential neighborhoods in the service areas of the local clinics and calculations of the distance from the reference points to the monitoring stations (Figure 2).

Interpolation of the baseline pollutant concentrations was conducted at the reference points; the obtained data was later used for the purposes of risk assessment. Baseline values such as average concentrations and the coefficient of variation can be obtained in a monitoring area by interpolation of the values obtained at the fixed-site stations [2]. Interpolation of the values was carried out in Panorama - 2011 GIS (Geographic Information System) and calculated separately for the wind speed ranges of $0-2 \mathrm{~m} / \mathrm{s}$ and $3.5 \mathrm{~m} / \mathrm{s}$.

The monitoring stations of the Lipetsk Center for Hydrometeorology and Environmental Monitoring, Hydraulic Systems company, and the Hygiene and Epidemiology Center for the Lipetsk Region were geocoded and added to the map of Lipetsk. Following the guidelines outlined in the regulatory document RD 52.04.186-89 - Guidelines for the control of air pollution (Clause 9.8.3), a "center of balance" was determined for the network of monitoring stations, i.e. a point the coordinates of which constitute an arithmetic average of the corresponding coordinates of the monitoring stations. Then we identified a station that was most remote from the center of balance; and then drew a circle around the center of balance with the radius $1.1 \mathrm{R}$ (Figure 3) 


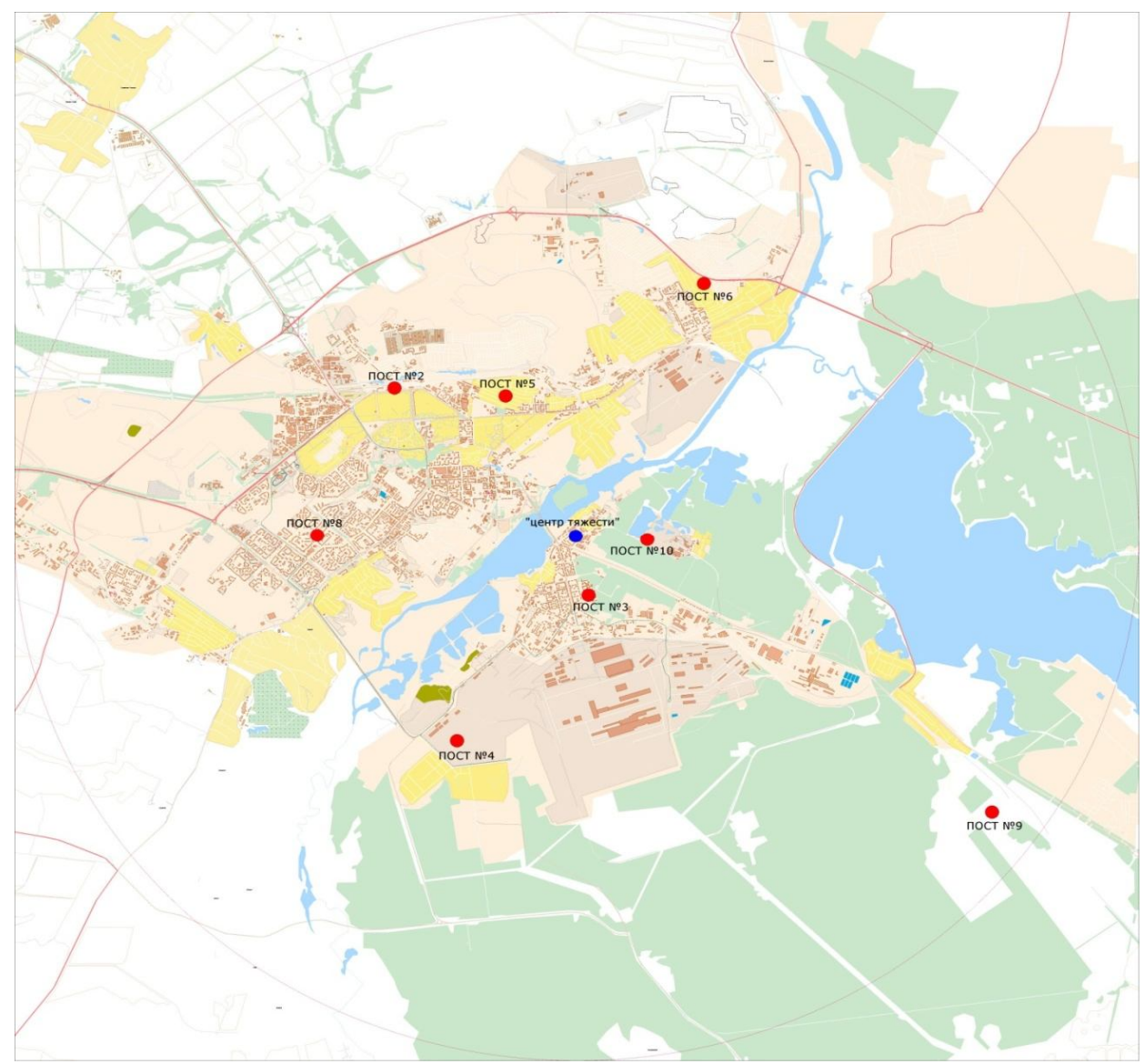

Figure 2: Reference points in the service areas of the local clinics.

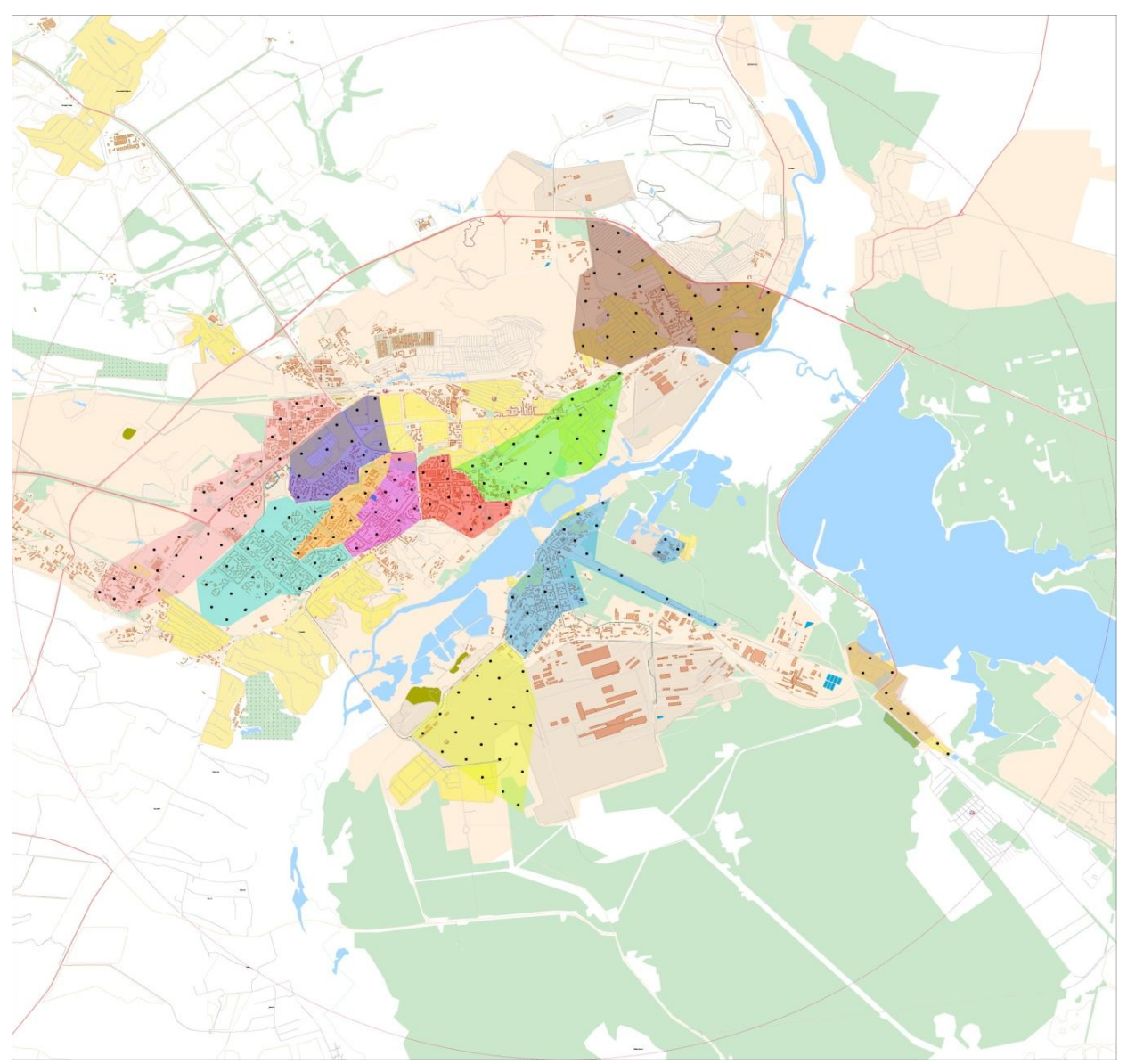

Figure 3: Identification of the "center of balance" for the network of monitoring stations 
Interpolation of the baseline values was calculated based on the formula below:

$$
\mathrm{C} \phi=\frac{\sum \mathrm{C} \phi \kappa / r_{k}}{\sum 1 / r_{k}}
$$

where Сфк and Сф are baseline concentrations at the k-th monitoring station and at the point in question (for the corresponding gradation of the wind speed and direction);

$\mathrm{rk}$ is a distance from the point in question to the $\mathrm{k}$-th station.

When conducting the calculations we took into account that if a point in question is located farther than $5 \mathrm{~km}$ from the nearest stations, then specification of the baseline values in relation to the wind is not practical as local conditions may make significant changes depending on the level of pollution resulting from the wind direction, and a margin of error of the interpolated baseline values may turn out to be greater than the error of neglecting the effect of the wind direction [2]. The obtained results were used to analyze carcinogenic and noncarcinogenic risks. Analysis of non- carcinogenic risk was conducted by determining the total hazard index for the substances with unidirectional impacts for chronic effects.

Research results. The results of the health risk assessment performed according to a standard scheme showed that in 2010 the level of carcinogenic risk in adults for all the substances falls in the second and third risk ranges, and carcinogenic risk of the children population falls in the first and second risk ranges. In 2012, the level of individual carcinogenic risk in children for all the substances (except for ethylbenzene) falls in the 1st risk range, and the risk of development of carcinogenic substances as a result of ethylbenzene impact falls in the 2nd risk range. Cancer risk in adults decreased to the second risk range (with the exception of ethylbenzene). Individual risk in adults resulting from ethylbenzene increased to the third range.

Table 2

Results of individual cancer risk calculations

\begin{tabular}{|c|c|c|c|c|c|c|c|}
\hline $\begin{array}{l}\text { Mo } \\
\text { nit }\end{array}$ & & $\begin{array}{l}\text { CR } \\
\text { Adults }\end{array}$ & $\begin{array}{c}\text { CR } \\
\text { Children }\end{array}$ & $\begin{array}{l}\text { CR } \\
\text { Adults }\end{array}$ & $\begin{array}{c}\text { CR } \\
\text { Children }\end{array}$ & $\begin{array}{l}\text { CR } \\
\text { Adults }\end{array}$ & $\begin{array}{c}\text { CR } \\
\text { Children }\end{array}$ \\
\hline $\begin{array}{l}\text { ng } \\
\text { stat } \\
\text { ion } \\
\text { No. }\end{array}$ & $\begin{array}{l}\text { Names of the } \\
\text { substance }\end{array}$ & \multicolumn{2}{|c|}{2010} & \multicolumn{2}{|c|}{2011} & \multicolumn{2}{|c|}{2012} \\
\hline 2 & Formaldehyde & $1.01 \mathrm{E}-04$ & $8,07 \mathrm{E}-06$ & $6,30 \mathrm{E}-05$ & $5.04 \mathrm{E}-06$ & $8,82 \mathrm{E}-05$ & $4,60 \mathrm{E}-07$ \\
\hline 3 & Benzo(a)pyrene & $2.14 \mathrm{E}-06$ & $1.71 \mathrm{E}-07$ & $1.71 \mathrm{E}-06$ & $1.37 \mathrm{E}-07$ & $1.82 \mathrm{E}-06^{*}$ & $1.45 \mathrm{E}-07^{*}$ \\
\hline 4 & Formaldehyde & $8,82 \mathrm{E}-05$ & $7,06 \mathrm{E}-06$ & $6,30 \mathrm{E}-05$ & 5.04E-06 & $7,56 \mathrm{E}-05$ & $3,95 \mathrm{E}-07$ \\
\hline 6 & Formaldehyde & $1.13 \mathrm{E}-04$ & $9.07 \mathrm{E}-06$ & $6,30 \mathrm{E}-05$ & $5.04 \mathrm{E}-06$ & $8,82 \mathrm{E}-05$ & $4,60 \mathrm{E}-07$ \\
\hline 6 & Benzo(a)pyrene & $1.84 \mathrm{E}-06$ & $1.47 \mathrm{E}-07$ & $1.60 \mathrm{E}-06$ & $1.28 \mathrm{E}-07$ & $1.82 \mathrm{E}-06^{*}$ & $1.45 \mathrm{E}-07 *$ \\
\hline 8 & Formaldehyde & $8,82 \mathrm{E}-05$ & $7,06 \mathrm{E}-06$ & $5.04 \mathrm{E}-05$ & 4.03E-06 & $7,56 \mathrm{E}-05$ & $3,95 \mathrm{E}-07$ \\
\hline 8 & Benzo(a)pyrene & $2.05 \mathrm{E}-06$ & $1.64 \mathrm{E}-07$ & $1.60 \mathrm{E}-06$ & $1.28 \mathrm{E}-07$ & $1.82 \mathrm{E}-06^{*}$ & $1.45 \mathrm{E}-07 *$ \\
\hline 5 & Formaldehyde & $1.89 \mathrm{E}-04$ & $9.86 \mathrm{E}-07$ & $1.26 \mathrm{E}-04$ & $1.01 \mathrm{E}-05$ & $1.01 \mathrm{E}-04$ & $5.26 \mathrm{E}-07$ \\
\hline 5 & Benzene & $1.33 \mathrm{E}-04$ & $1.07 \mathrm{E}-05$ & $2.81 \mathrm{E}-04$ & $2.25 \mathrm{E}-05$ & $9.28 \mathrm{E}-07$ & $7.43 \mathrm{E}-08$ \\
\hline 5 & Ethylbenzene & $2.11 \mathrm{E}-06$ & $1.69 \mathrm{E}-07$ & $4.22 \mathrm{E}-06$ & $3.38 \mathrm{E}-07$ & $2.44 \mathrm{E}-04$ & $1.95 \mathrm{E}-05$ \\
\hline 5 & $\begin{array}{l}\text { Lead and its } \\
\text { inorganic }\end{array}$ & $1.04 \mathrm{E}-06$ & $8.28 \mathrm{E}-08$ & $6.90 \mathrm{E}-07$ & $5.52 \mathrm{E}-08$ & $1.73 \mathrm{E}-06$ & $1.38 \mathrm{E}-07$ \\
\hline
\end{tabular}




\begin{tabular}{|c|c|c|c|c|c|c|c|}
\hline \multirow{2}{*}{$\begin{array}{c}\text { Mo } \\
\text { nit } \\
\text { ori }\end{array}$} & \multirow{2}{*}{$\begin{array}{c}\text { Names of the } \\
\text { ng }\end{array}$} & $\begin{array}{c}\text { CR } \\
\text { Adults }\end{array}$ & $\begin{array}{c}\text { CR } \\
\text { Children }\end{array}$ & $\begin{array}{c}\text { CR } \\
\text { Adults }\end{array}$ & $\begin{array}{c}\text { CR } \\
\text { Children }\end{array}$ & $\begin{array}{c}\text { CR } \\
\text { Adults }\end{array}$ & $\begin{array}{c}\text { CR } \\
\text { Children }\end{array}$ \\
\cline { 3 - 8 } ion & substance & \multicolumn{2}{|c|}{2010} & \multicolumn{2}{|c|}{2011} & \multicolumn{2}{|c|}{2012} \\
No. & & \multicolumn{2}{|c|}{2010} & & \\
\hline & compounds & & & & & \\
\hline
\end{tabular}

* After the final results have been obtained from the monitoring stations in Lipetsk, the risk levels will be recalculated.

In 2012, the total cancer risk at the 5, 6 and 8 stations decreased in both adults and for children as compared to 2010 (Table 3)

Table 3

Total cancer risk in Lipetsk

\begin{tabular}{|c|c|c|c|c|c|c|}
\hline \multirow{2}{*}{$\begin{array}{c}\text { Monitoring } \\
\text { station No. }\end{array}$} & \multicolumn{2}{|c|}{2010} & \multicolumn{2}{c|}{2011} & \multicolumn{2}{c|}{2012} \\
\cline { 2 - 7 } & Adults & Children & Adults & Children & Adults & Children \\
\hline 5 & $4.36 \mathrm{E}-04$ & $2.08 \mathrm{E}-05$ & $4.12 \mathrm{E}-04$ & $3.30 \mathrm{E}-05$ & $3.48 \mathrm{E}-04$ & $3.03 \mathrm{E}-05$ \\
\hline 6 & $1.15 \mathrm{E}-04$ & $9.22 \mathrm{E}-06$ & $6,46 \mathrm{E}-05$ & $5.17 \mathrm{E}-06$ & $9.00 \mathrm{E}-05$ & $6,06 \mathrm{E}-07$ \\
\hline 8 & $9.03 \mathrm{E}-05$ & $7.22 \mathrm{E}-06$ & $5.20 \mathrm{E}-05$ & $4.16 \mathrm{E}-06$ & $7.74 \mathrm{E}-05$ & $5,4 \mathrm{E}-07$ \\
\hline
\end{tabular}

Formaldehyde and ethylbenzene had the biggest impact on the development of cancer risks in the city. The data below shows that non-cancer risk in adults exceeds the value of 1 for substances such as formaldehyde, benzo(a)pyrene, hydrogen sulfide, and nitrogen (IV) oxide .

Table 4

Results of non- cancer risk calculations

\begin{tabular}{|c|l|c|c|c|}
\hline \multirow{2}{*}{$\begin{array}{c}\text { Monitoring } \\
\text { station No. }\end{array}$} & \multicolumn{1}{|c|}{ Names of the substance } & \multicolumn{3}{c|}{ HQ } \\
\cline { 3 - 5 } & & 2010 & 2011 & 2012 \\
\hline 2 & $498:$ Carbon monoxide & 0.33 & 0.33 & 0.33 \\
\hline 2 & $5:$ Nitrogen (IY) oxide & 0.25 & 0.25 & 0.25 \\
\hline 2 & $438:$ Hydrogen Sulfide & 0.50 & 0.50 & 0.50 \\
\hline 2 & $512:$ Phenol & 0.50 & 0.67 & 0.33 \\
\hline 2 & $522:$ Formaldehyde & 2.67 & 1.67 & 2.33 \\
\hline 3 & $498:$ Carbon monoxide & 0.33 & 0.33 & 0.33 \\
\hline 3 & $5:$ Nitrogen (IY) oxide & 0.25 & 0.25 & 0.25 \\
\hline 3 & $4:$ Nitrogen (II) Oxide & 0.17 & 0.17 & 0.17 \\
\hline 3 & $438:$ Hydrogen Sulfide & 1.00 & 1.00 & 1.00 \\
\hline 3 & $436:$ Sulfur dioxide & 0.12 & 0.05 & 0.08 \\
\hline 3 & $512:$ Phenol & 0.50 & 0.67 & 0.33 \\
\hline 3 & $48:$ Benzo(a)pyrene & 2.00 & 1.60 & 1.7 \\
\hline 4 & $498:$ Carbon monoxide & 0.33 & 0.33 & 0.33 \\
\hline 4 & $5:$ Nitrogen (IY) oxide & 0.25 & 0.25 & 0.25 \\
\hline 4 & $438:$ Hydrogen Sulfide & 1.00 & 1.00 & 1.00 \\
\hline 4 & $512:$ Phenol & 0.50 & 0.67 & 0.33 \\
\hline 4 & $522:$ Formaldehyde & 2.33 & 1.67 & 2.00 \\
\hline
\end{tabular}




\begin{tabular}{|c|c|c|c|c|}
\hline \multirow{2}{*}{$\begin{array}{l}\text { Monitoring } \\
\text { station No. }\end{array}$} & \multirow{2}{*}{ Names of the substance } & \multicolumn{3}{|c|}{ HQ } \\
\hline & & 2010 & 2011 & 2012 \\
\hline 5 & 498: Carbon monoxide & 0.72 & 0.36 & 0.34 \\
\hline 5 & 5 : Nitrogen (IY) oxide & 2.25 & 1.25 & 1.05 \\
\hline 5 & $522:$ Formaldehyde & 5.00 & 3.33 & 2.67 \\
\hline 5 & 436: Sulfur dioxide & - & 0.36 & 0.19 \\
\hline 5 & 57 : Benzene & 0.60 & 1.27 & 1.10 \\
\hline 5 & $\begin{array}{l}273 \text { Xylene (mixed isomers of o-, } \mathrm{m}-\text {, } \\
\mathrm{p}-\text { ) }\end{array}$ & 0.06 & 0.09 & 0.04 \\
\hline 5 & $473:$ Toluene & 0.04 & 0.05 & 0.03 \\
\hline 5 & $582:$ Ethylbenzene & 0.002 & 0.004 & 0.001 \\
\hline 5 & $\begin{array}{l}433 \text { : Lead and its inorganic } \\
\text { compounds ( calculated for lead) }\end{array}$ & 0.18 & 0.12 & 0.30 \\
\hline 6 & 498: Carbon monoxide & 0.33 & 0.33 & 0.33 \\
\hline 6 & 5 : Nitrogen (IY) oxide & 0.50 & 0.50 & 0.25 \\
\hline 6 & 438 : Hydrogen Sulfide & 1.00 & 1.50 & 1.00 \\
\hline 6 & $512:$ Phenol & 0.33 & 0.67 & 0.33 \\
\hline 6 & 522 : Formaldehyde & 3.00 & 1.67 & 2.33 \\
\hline 6 & 48 : Benzo(a)pyrene & 1.72 & 1.50 & $1.7^{*}$ \\
\hline 8 & 498 : Carbon monoxide & 0.33 & 0.33 & 0.33 \\
\hline 8 & 5 : Nitrogen (IY) oxide & 0.25 & 0.50 & 0.25 \\
\hline 8 & 438 : Hydrogen Sulfide & 1.00 & 1.00 & 1.00 \\
\hline 8 & $512:$ Phenol & 0.50 & 0.67 & 0.33 \\
\hline 8 & 522 : Formaldehyde & 2.33 & 1.33 & 2.00 \\
\hline 8 & 48 : Benzo(a)pyrene & 1.92 & 1.50 & $1.7^{*}$ \\
\hline 9 & 498: Carbon monoxide & - & 0.50 & 0.43 \\
\hline 9 & 5 : Nitrogen (IY) oxide & 0.95 & 0.93 & 0.48 \\
\hline 9 & 438 : Hydrogen Sulfide & 1.50 & 1.55 & 1.00 \\
\hline 9 & 436: Sulfur dioxide & 0.24 & 0.26 & 0.11 \\
\hline 9 & $512:$ Phenol & 0.50 & 0.48 & 0.50 \\
\hline 10 & 498: Carbon monoxide & 2.84 & 0.33 & 0.33 \\
\hline 10 & 5 : Nitrogen (IY) oxide & 0.50 & 0.25 & 0.30 \\
\hline 10 & 438 : Hydrogen Sulfide & 1.50 & 1.50 & 1.15 \\
\hline 10 & $436:$ Sulfur dioxide & 0.08 & 0.06 & 0.07 \\
\hline 10 & $512:$ Phenol & 0.50 & 0.67 & 0.37 \\
\hline
\end{tabular}

* After the final results have been obtained from the monitoring stations in Lipetsk, the risk levels will be recalculated.

The results of the risk levels obtained using the interpolated values of the baseline concentrations showed that the current individual cancer risk levels in the areas of environmental concern range from 7.47 E-05 to 3.61 E-04 thus falling in the second and third risk ranges. Ethylbenzene and formaldehyde had the biggest impact on the development of individual cancer risk in the city.

The situation is different when it comes to non-carcinogenic effects. Due to the fact that the area in question is exposed to multi-component chemical pollution, the study of the 
cumulative risks resulting from simultaneous exposure to several chemical compounds is of great interest. The hazard indices were calculated individually for the 12 allocated affected body systems at the current state. Table 5 shows the results of a chronic effect risk analysis for the total hazard index (HI) for the substances with a unidirectional impact; the results are presented by zones based on the medical service areas.

Table 5

Total chronic non-cancer effects risk index in 2012

\begin{tabular}{|c|c|c|c|}
\hline \multirow[t]{2}{*}{ Medical service areas (by local clinics) } & \multicolumn{3}{|c|}{ Hazard Index } \\
\hline & $\begin{array}{l}\text { Respirator } \\
\text { y organs }\end{array}$ & Eye & Immunity \\
\hline $\begin{array}{l}\text { Municipal Institution (MI) City Hospital "Lipetsk- } \\
\text { Med" }\end{array}$ & 3.59 & 2.00 & 2.00 \\
\hline $\begin{array}{l}\text { Municipal Health Care Institution (MHCI) "Children's } \\
\text { City Clinic No. 5" }\end{array}$ & 3.67 & 1.71 & 1.52 \\
\hline MHCI "City Clinic No. 3" & 3.94 & 2.41 & 2.39 \\
\hline Municipal Hospital "Svobodny Sokol" (Free Falcon) & 3,91 & 4.03 & 2.33 \\
\hline MHCI “City Clinic No. 2" & 3.42 & 2.31 & 2.31 \\
\hline $\begin{array}{l}\text { Private Institution "Training, production and } \\
\text { preventive medical center" }\end{array}$ & 2.13 & 1.34 & 1.34 \\
\hline MI "City Children's Hospital No. 1" & 3.89 & 2.67 & 2.67 \\
\hline $\begin{array}{l}\text { Non-commercial partnership "Novolipetskij Medical } \\
\text { Center" }\end{array}$ & 1.89 & 2.03 & 2.03 \\
\hline MHCI “City Clinic No. 4” & 3.61 & 1.93 & 1.93 \\
\hline MI “City Children's Hospital No. 2" & 3.45 & 1.41 & 1.41 \\
\hline MHCI "City Clinic No. 6" & 3.59 & 3.71 & 2.33 \\
\hline MI "City Clinic No. 1" & 3.57 & 1.96 & 1.96 \\
\hline MI “City Hospital No. 2" & 3.44 & 3.31 & 2.17 \\
\hline MI “City Hospital No. 5” & 3.44 & 2.33 & 2.33 \\
\hline $\begin{array}{l}\text { Municipal Prevention and Treatment Facility (MPTF) } \\
\text { "Clinic No. 5" }\end{array}$ & 3.34 & 2.13 & 2.13 \\
\hline MHCI “City Clinic No. 8” & 1.88 & 1.12 & 1.12 \\
\hline MHCI "City Hospital No. 3" & 3.23 & 2.12 & 2.12 \\
\hline
\end{tabular}

Table 4 shows that in all the medical service areas the risk of respiratory diseases and negative impact on the eyes and the immunity exceeds the permissible level. The hazard indices for the remaining 9 affected systems (blood, kidney, liver, reproductive system, overall development, red bone marrow, and hormone system) do not exceed 1.

The main non-carcinogenic polluters include formaldehyde, ben(a)pyrene, and hydrogen sulfide, the hazard coefficient of which are 1.93, 1.7 and 1.15 respectively. Formaldehyde has the biggest impact on the total HI value and the development of negative effects on the respiratory system.

The analysis of the total disease incidence in the area showed that in the assessment period (2010-2012) the overall incidence of all types of diseases in children (0-14 years old) increased in the medical service areas served by the Municipal Hospital "Svobodny Sokol", the City Children's Clinic No. 5, and the City Children's Hospital No. 2. As for other medical institutions for children, the total number of diseases decreased. 
The incidence of some diseases in children increased in 2012 as compared to 2010: the number of reported cases of respiratory diseases in the City Children's Hospital No. 1 increased by $7.47 \%$, in the City Children's Hospital No. 2 - increased by $12.84 \%$, and in the Municipal City Children's Clinic No. 5 and the "Svobodny Sokol" Hospital - increased by $11.63 \%$ and $28.79 \%$ respectively.

The incidence of malignant growths increased in the service areas of the City Children's Hospital No. 2, the City Children's Clinic No. 5, and the "Svobodny Sokol" Hospital.

The overall incidence of all types of diseases in adolescents (15-17 years old) increased in the service areas of the City Children's Hospital No. 2. In the service area of the City Hospital No. 2, the incidence remained the same. In the service areas of other medical institutions for adolescents, the total number of diseases decreased. The number of certain classes of diseases in teenagers went up in 2012 as compared to 2010 :

- Respiratory diseases in the service areas of the Children's City Clinic No. 5;

- Malignant growths in the service areas of the City Children's Hospital No. 2 and the Hospital "Lipetsk-Med";

The overall incidence of all types of diseases in adults (18 years old and up) went up in the service area of the City Clinic No. 6. In the service area of the City Clinic No. 4, the incidence remained the same. As for other medical institutions for adults, the total number of diseases decreased. However in 2012, the number of certain classes of diseases in adults increased as compared to 2010 :

- Respiratory diseases in the service areas of the City Clinic No. 4, the City Clinic No. 1, the City Clinic No. 6, the Clinic No. 5, and the City Clinic No. 3;

- Malignant growths in the service areas of the City Clinic No. 1, the Clinic No. 5, the City Clinic No. 3, the City Hospital No. 2, and the City Hospital "Lipetsk-Med".

Specific numerical values of risk in the present work are of relative nature and can be taken into account only in the context of all the uncertainty factors, identified in the research as well as with many unaccounted factors affecting the quality of the final estimates; however these values reflect the quantitative characteristics of potential health damage resulting from exposure to various chemicals in Lipetsk and trends of its generation.

Conclusions. As can be seen from the above, quantitative assessment of the health effects associated with air pollution was conducted on the basis of social-hygienic monitoring. The obtained values for the levels of individual cancer and non-cancer risks in different age groups in Lipetsk give an opportunity to adjust the regional target programs focusing on the identified areas of concern and provide support for the management decision-making in the field of sanitary and epidemiological well-being of the population and its effectiveness.

This research can be used as the grounds for implementation of various rehabilitation programs aimed at people with high health risks associated with environmental exposure and reasonably select the areas and the at-risk groups for the implementation of future rehabilitation activities.

\section{References}

1. Fomin G.S., Fomina O.N. Vozdukh. Kontrol' zagryazneniya po mezhdunarodnym standartam. Spravoch-nik [Air. Pollution monitoring according to international standards. A reference book]. 2 ed. Moscow: Protektor, 2002. 432 p. 
2. RD 52.04.186-89. Rukovodstvo po kontrolyu zagryazneniya atmosfery [RD 52.04.186-89. Guidelines for ambient air pollution control]. Available at: http: // www.gosthelp.ru/ text/RD520418689 Rukovodstvopok.html.

3. R 2.1.10.1920-04. Rukovodstvo po otsenke riska dlya zdorov'ya naseleniya pri vozdeystvii khimicheskikh veshchestv, zagryaznyayushchikh okruzhayushchuyu sredu [R 2.1.10.1920-04. Guidelines for human health risk assessment of exposure to environmental chemical pollutants]. Available at: http: //www.znaytovar.ru/ gost/2/R_2110192004_Rukovodstvo_po_oc.html.

\section{A bout the a uthor s :}

Lipetsk Region Department of the Federal Service on Customers Rights Protection and Human Well-Being Surveillance (Lipetsk), 398002 , 60a Gagarin st., E-mail: ocgsen@lipetsk.ru

Stanislav Ivanovich Saveliev - M.D., Professor, Head of the Lipetsk Region Department of the Federal Service on Customers Rights Protection and Human Well-Being Surveillance, Head, Department of Hygiene, Epidemiology and Laboratory Work at the Mechnikov Northwestern State Medical University, the Ministry of Public Health and Social Development of the Russian Federation, Ph. (4742) 27-00-76,.

Yelena Alekseyevna Golovanova - Deputy Head, Department of Public Health Monitoring, Associate, Department of Hygiene, Epidemiology and Laboratory Work at the Mechnikov Northwestern State Medical University, the Ministry of Public Health and Social Development of the Russian Federation, Ph. (4742) 30-88-40.

Vyacheslav Mikhailovich Saltykov - Deputy Head of the Department of Activity Management, Associate, Department of Hygiene, Epidemiology and Laboratory Work at the Mechnikov Northwestern State Medical University, the Ministry of Public Health and Social Development of the Russian Federation, Ph. (4742) 30-88-34.

Federal state budgetary institution (FSBI) Hygiene and Epidemiology Center for the Lipetsk Region, 398002, 60a Gagarin st., E-mail: orgotdel@fguz.lipetsk.ru

Vladimir Aleksandrovich Bondaryov - M.D., Professor, Chief Medical Officer, Professor, Department of Hygiene, Epidemiology and Laboratory Work at the Mechnikov Northwestern State Medical University, the Ministry of Public Health and Social Development of the Russian Federation, Ph. (4742) 30-86-50.

Marina Fyodorovna Polyakova - Candidate of Medical Sciences, Head, Section for the Organizational Activity, Metrology and Expertise, and Public Health Monitoring, Assistant, Department of Hygiene, Epidemiology and Laboratory Work at the Mechnikov Northwestern State Medical University, the Ministry of Public Health and Social Development of the Russian Federation, Ph. (4742) 30-86-65.

Natalia Vladimirovna Nakhichevanskaya - Head, Department for the Social and Hygienic Monitoring and Risk Assessment, Ph. (4742) 30-86-98.

Grigoriy Anatolievich Yuriev - General Hygiene Doctor, Department for the Social and Hygienic Monitoring and Risk Assessment, Ph. (4742) 30-86-98. 